\title{
Cyberbullying and Criminal Law
}

\author{
Gülşah Bostancı Bozbayındır * (1)
}

\begin{abstract}
As a result of the rapid growth and availability of information and communication technology (ICT) traditional bullying and harassment activities have started to appear on the internet. Current forms of cyberbullying and cyberharassment are a cause of great concern with respect to children's safety and well-being. Cyberbullying lacks a universally accepted definition, namely there is no consensus on a single definition of cyberbullying - which is, after all, generally understood as bullying occurring on the internet - determined at an international or European level. However, in this study we have identified the distinctive features of cyberbullying, that is, the high degree of anonymity, power imbalance between the offencer and the victim, potentially public nature of cyberbullying and defencelessness of the victim, and the high probablity of repetition with anonymity being one of the unique features of cyberbullying. We shall analyse all these elements of cyberbullying, respectively. After this conceptual analysis, we shall assess the approaches and solutions that have been adopted towards cyberbullying in a comparative manner. Finally, we will address the question of whether acts of cyberbulllying should be criminalized and we will discuss the employability of options other than criminal law.
\end{abstract}

\section{Keywords}

Cyberbullying • Bullying • ICT • Criminal law

\section{Siber Zorbalık ve Ceza Hukuku}

\section{Öz}

Bilişim ve iletişim teknolojilerinin hızlı gelişimi ve ulaşılabilirliği, taciz ve benzer nitelikteki olayların internet üzerinden gerçekleştirilmeleri sonucunu doğurmaktadır. Yüz yüze tacizden farklı olarak siber taciz ya da zorbalık olayları çok çeşitli fiilleri kapsayacak biçimde ve bu nedenle birçok görünüm biçimini de içeren dünya genelinde yeni bir fenomen haline gelmiştir. Her ne kadar henüz siber tacize ilişkin gerek Avrupa gerekse dünya genelinde ortak bir tanım yapılmamışsa da en basitiyle internet üzerinden gerçekleştirilen taciz, zorbalık anlamına gelmektedir. Siber taciz vakalarının işlenme sıklığı ve sayısı her geçen gün daha da artma eğilimi göstermekte, tacizcilerin internet kullanma oranı da artı̧̧ göstermesi ile beraber özellikle çocukların bu fiillere maruz kalma intimali de yükselmektedir. İnternet ortamında gerçekleşen siber taciz vakaları çocukların güvenliği ve refahı bakımından büyük bir endişe kaynağı teşkil etmektedir. Bu nedenle, çalışmamızda siber taciz kavramının başat unsurlarını tespit etmeye çalıştı. Bu unsurlar, yüksek seviye anonimlik, mağdurun kendini savunma imkanlarının büyük ölçüde kısıtlanmış olması ve tekerrür ihtimalinin oldukça yüksek olmasıdır. Çalışmamızda, siber taciz kavramının bu ayırıcı vasıflarını sırasıyla tahlil edeceğiz. Bu kavramsal analizin akabinde, karşılaştırmalı hukukta siber taciz konusunda benimsenen yaklaşım ve çözümleri değerlendireceğiz. Nihayet, siber taciz fiillerinin suç haline getirilip getirilmemesi gerektiği sorusunu ve ceza hukuku dışındaki çözüm ihtimallerini ele alacağız.

\section{Anahtar Kelimeler \\ Taciz • Siber taciz • Ceza hukuku • Bilgi ve iletişim teknolojileri}

\footnotetext{
* Correspondence to: Gulsah Bostanci Bozbayindir (Dr. Lecturer), Istanbul Sabahattin Zaim University, Faculty of Law, Department of Criminal and Criminal Procedure Law, Istanbul, Turkey. Email: gulsah_bostanci@yahoo.com ORCID: 0000-0003-0602-2713
}

To cite this article: Bostanci Bozbayindir G, "Cyberbullying and Criminal Law" (2019) 77(1) Istanbul Law Review 425 https://doi.org/10.26650/mecmua.2019.77.1.0009 


\section{Introduction}

As a result of the rapid growth and availability of information and communication technology (ICT), new risks related to privacy have begun to emerge. One of these risks is that traditional bullying and harassment activities have started to appear on the internet. Indeed, current forms of cyberbullying and cyber harassment are a cause of great concern with respect to children's safety and well-being. Furthermore, the numbers and frequency of cyberbullying cases have a tendency to increase rapidly and children have encountered a more widespread contact risk on the internet in recent years ${ }^{1}$ because people have started to increasingly use the internet to slander ${ }^{2}$ and cyberbully other people 3 . For instance, according to a recent study conducted by the Cyberbullying Research Center in America, in 2016 approximately 34\% of students reported experiencing cyberbullying and approximately $12 \%$ of students admitted that they had committed acts of cyberbullying against others at some point in their lifetime. According to the 2014 EU Kids Online and Net Children Go Mobile Report ${ }^{4}$, cyberbullying and negative forms of user-generated content are on the rise among girls and in the youngest age group (9-16 years) from $8 \%$ to $12 \%$. According to another report issued by the Counselling Service from Northern Ireland, $25 \%$ of adolescents reported that they had struggled with repeated bullying on their mobile phone or on the Internet and 52\% of adolescents reported being cyberbullied. About half of young people have also reported other forms of cyberbullying they were facing. Among these young people, almost $20 \%$ experience cyber bullying regularly ${ }^{5}$. This data is also verified in the i-SAFE Foundation survey ${ }^{6}$. One out of every three (34\%) children in the United Kingdom have been exposed to cyberbullying, exposed to damaging content of a website encouraging self-harm or saw some other type of negative consequences when using social media ${ }^{7}$.

The statistics given above show that there have been many incidents in which young people harmed themselves or committed suicide as a result of an act of bullying which took place online - such as the case of Megan Meier, which will be analysed below. Such incidents may be extreme, but it is often the case, especially among young people, that they are pressured primarily online, and their personality is systematically destroyed via the Internet. Typically, a perpetrator begins the cyberbullying by sharing opinions or posting images of the victim. The individual

\footnotetext{
Milda Macenaite, Regulation of Children's Online Privacy, (Tilburg University Research Master Paper 2012), 7.

Krupa Patel, ‘Cyberbullying: What's the Status in England?', (2011-2012) (13) San Diego International Law Journal, 589, 602. Patel (n 2) 590.

$4<$ http://netchildrengomobile.eu/ncgm/wp-content/uploads/2014/11/EU-Kids-Online-Net-Children-Go-Mobilecomparative-report.pdf $>$ accessed 12 December 2018

$<$ https://nobullying.com/cyber-bullying-statistics-2014/> accessed 6 November 2018

$<$ https://www.isafe.org/outreach/media/media_cyber_bullying > accessed 24 June 2019

$<$ https://www.theguardian.com/technology/2017/jun/30/british-teenagers-among-worlds-most-extreme-internet-usersreport-says $>$ accessed 15 March 2018
} 
threat, insult, harassment or exclusion is not a a criminal offense, nor is spreading individual embarrassing photos. As in stalking, perpetrators act systematically and the acts or their effects continue for a long time. It is particularly traumatic for a victim of cyberbullying that there appears to be no escape.

\section{Definitional Issues and the Unique Nature of Cyberbullying}

\section{A. Definitions of Cyberbullying}

\section{General Remarks}

In comparison with traditional/face-to-face bullying ${ }^{8}$, cyberbullying is a relatively new worldwide phenomenon which encompasses a wide variety of acts and therefore has several subtypes. Cyberbullying lacks a universally accepted definition, namely there is no consensus on a single definition of cyberbullying - which is, after all, generally understood as bullying occurring on the internet - determined at an international or European level, ${ }^{9}$. Put generally, current conceptions of cyberbullying treat the subject merely as a form of traditional bullying, which is committed through novel means ${ }^{10}$.

Indeed, cyberbullying and bullying in its traditional forms share a common trait, that is, the element of repetition or the continuous nature of acts. It should not be forgotten that, with some exceptions, cyberbullying is an extension of traditional face-to-face bullying ${ }^{11}$. In the literature, it has been argued whether cyberbullying is either an umbrella term to cover electronic bullying and internet harassment ${ }^{12}$ or it is face-to-face bullying retaining some of the main elements including repetition, power imbalance and intention ${ }^{13}$. The content of cyberbullying encompass not only harassment - which includes (but is not limited to), aggressive acts, sexual abuse, physical threats, mobbing or insulting others but also includes social bullying such as non-verbal cues signalling the intent to spread rumours, slander, social inclusion and the like $\mathrm{e}^{14}$.

\footnotetext{
'Face-to-face bullying is regarded as an abusive relationship that involves repeated, intentionally hurtful acts directed towards a target who is less powerful than the perpetrator and is unable to defend themselves' Lucy R. Betts, Cyberbullying. Approaches, Consequences and Interventions, (Palgrave 2016) 29.

9 Cyberbullying among young people, <www.europarl.europa.eu/RegData/etudes/STUD/.../IPOL_STU(2016)>, 8. accessed 13 April 2018

10 Philipp Pelka, 'Cybermobbing und die Notwendigkeit einer neuen Strafrechtsnorm in Deutschland' (Grin Verlag 2015) 2.

11 <http://oecdeducationtoday.blogspot.com.tr/2014/10/combatting-bullying-in-schools.html> accessed 14 April 2018; Nicole Weber and William V. Jr. Pelfrey, Cyberbullying-Consequences, Causes and Coping Strategies (Lfb Scholarly Pub 2014) 30.

12 R.S. Tokunga, 'Following you home from school: A critical review and synthesis of research on cyberbullying victimization' 26 (3) Computers in Human Behaviour 277, 277.

13 D. Olweus, 'School Bullying: Development and Some Important Challenges', (2013) (9) Annual Review of Clinical Psychology 751, 752, Kimberly L. Mason, 'Cyberbullying: A Preliminary Assessment for School Personell, Psychology in the Schools' (2008) 45(4) Psychology in the Schools, 323, $324<$ https://onlinelibrary.wiley.com/doi/epdf/10.1002/ pits.20301> accessed 21 June 2019, J. Wang, R.J. Iannotti and J.W. Luk, 'Patterns of Adolescent Bullying Behaviours: Physical, Verbal, Exclusion, Rumor and Cyber' (2012) 50(4) Journal of School Psychology 521, 534.for the different detailed definitions of cyberbullying: Nicole Weber, V.William and Jr. Pelfrey, (no 11) $32 \mathrm{ff}$.

14 A Millwood Hargrave, 'Protecting Children from Harmful Content Report Prepared for the Council of Europe's Group
} 
According to the OECD Report of 2018, cyberbullying is defined as 'an aggressive, intentional act carried out by a group or individuals, using electronic forms of contact, repeatedly and over time against a victim who cannot easily defend him or herself' ${ }^{\prime 1}$. Both bullying and cyberbullying are aggressive conducts whose objective is to harm another person. Thus, in this way, cyberbullying possesses another feature that deserves its distinct treatment vis-a-vis traditional bullying. Indeed, cyberbullying targets a victim's life in a repeated, continuous fashion through the use of ICTs. Most of the prerequisites of traditional bullying are also valid for the phenomenon of cyberbullying, that is, in both forms of bullying there are elements of aggressive behaviour, power imbalance between the perpetrator and the victim and repetition of harmful acts ${ }^{16}$. Cyberbullying is a "psychologically harmful form of social cruelty among peers" experienced through the means of electronic media and $\mathrm{ICT}^{17}$. In this respect, cyberbullying is a systematic abuse of power which takes place using internet technology by means of Facebook, twitter, etc ${ }^{18}$. That said, employment of new technologies further complicates the matter, since further elements such as anonymity cause difficulties with identifying the bully and the duration of bullying. These elements mark the distinctiveness of cyberbullying and its potential to cause more harm than traditional, face-to-face bullying. Self-evidently, the Digital World is a liberating environment which brings a lot of privileges but at the same has disadvantages and risks especially for young people including but this is by no means limited to cyberbullying. In this vein, we shall treat cyberbullying as a new form of bullying in its own right since there is growing evidence that cyberbullying represents a unique form of bullying. Despite the discrepancies in defining cyberbullying or the lack of consistency and consensus on the definition in the literature, the following requirements are generally acknowledged as the constitutive elements of an act of cyber-bullying: the power dynamic between the victim and the perpetrator, anonymity of perpetrator, repeated acts, high publicity ${ }^{19}$.

of Specialists on Human Rights in the Information Society' <www.coe.int/t/dghl/standardsetting/media/Doc/(2009)13 en.pdf,p. 8> accessed 27 March 2017; Betts (n 8) 13.

15 OECD Report on New Technologies and 21st Century Children: Recent Trends and Outcomes, Education Working Paper No. 179, s.24, <http://www.oecd.org/officialdocuments/publicdisplaydocumentpdf/> accessed 28 March 2018. Although there are many types of bullying, generally accepted as a form of harassment involving aggressiveness, intent to harm, repetition and a power imbalance between the bully and the bullied. For more detailed: <https://www.bullying.co.uk/ general-advice/what-is-bullying/> accessed 29 May 2018.

16 Peter Smith, Georges Steffgen and Ruth Sittichai, 'The Nature of Cyberbullying and an international Network' in Peter Smith and Georges Steffgen (eds) Cyberbullying through the new media (Psychology 2013) 26.

17 Shaheen Shariff, Dianne L. Hoff, 'Cyberbullying: Clarifying Legal Boundaries for School Supervision in Cyberspace', (2007) 1 (1) International Journal of Cyber Criminology, $76 \mathrm{ff}$.

18 Smitth, Steffgen and Sittichai (n 16) 26.; Weber (n 11) 30.

19 For detailed information and discussions: Betts (n 8) $10 \mathrm{ff}$. 'A recent research argued that the definitions of cyberbullying consist of four elements: (1) intentional aggressive behaviour that is (2)carried out repeatedly (3) occurs between a perpetrator and a victim who are unequal in power and (4) occurs through ICT. Kowalski, Giumatti, Schroder and Lattanner, 'Bullying in the Digital Age: A critical review and meta-analysis of cyberbullying research among youth' (2014) 4 (140) Psychological Bulletin 1073, 1137. Another research emphasis 'anonymity and potential public nature of cyberbullying as more important facets in definitions of cyberbullying'. H. Thomas, P. Connor and J. Scott, Integrating Traditional Bullying and Cyberbullying: Challenges of Definition and Measurement in Adolescents, (27) Education Psychology Review 135, 152. 


\section{Distinctive Features of Cyberbullying}

\section{a. A High Degree of Anonymity}

Anonymity is one of the unique features of cyberbullying. Anonymity and accessibility distinguish cyberbullying from traditional bullying. The anonymity of the perpetrator affects the victims in various ways. The degree of anonymity in cyberbullying can be very high, because perpetrators are not physically recognizable at first and can also be hidden behind a pseudonym (e.g., wrong profile or wrong profile photo) or they can manipulate their true identity. Hiding their identity gives the perpetrator more power over the victim, the perpetrators' actions are less likely to be judged by acquaintances and also anonymity encourages the perpetrator to increase the degree of fear ${ }^{20}$. As the online attacks cause the victim to feel isolated, become dehumanized and helpless, victims of cyberbullying are more likely to suffer from higher levels of depression ${ }^{21}$.

Anonymity also brings the lack of empathy. This element leads to more fear among victims, and they mostly do not find solution strategies faced with the difficulty in identifying perpetrators. Victims of cyberbullying who face continuous humiliation from an unidentified bully, are afraid that they cannot prove who was the perpetrator and they cannot ask for assistance from others. Additionally, perpetrators are committing the acts solely on the Internet meaning that a connection in the real environment - such as school - does not exist and perpetrators are in most cases not aware of the emotional symptoms that victims suffer as a result of an act of cyberbullying. In other words, the perpetrator does not witness the victim's reaction and therefore it encourages cyberbullying, because the lack of direct feedback prevents feelings of empathy with the victim or feeling sorry for him or her. This lack of empathy causes the perpetrator to use crueller language including threats that increases the level of fear that is gradually instilled into the heart of the victim, since he is helpless faced with the humiliation and seriousness of the threat.

One of the challenges is the issue of dark figures in such cases. Generally, it is a fact that cyberbullying cases ending in the suicide of the victims can fall within the criminal law. For example, a study has revealed that $40 \%$ of young people never report cyberbullying abuse. Moreover, the parents are reluctant to report such incidences ${ }^{22}$. When a minor becomes a victim, he/she is not even aware of the fact that the relevant conduct can constitute a crime or a wrongful act. The dark figures also can be explained by the fact that victims fear being labelled as a 'snitch'; the fear of making that situation worse and not taking the matter seriously

\footnotetext{
20 Betts (n 8) 44.

${ }_{21}$ Stephanie Chen, 'In a wired world, children unable to escape cyberbullying', <http://www.cnn.com/2010/LIVING/10/04/ youth.cyberbullying.abuse/index.html.http://www.nih.gov/news/health/sep2010/nichd-21.htm.> accessed 14 April 2018.

$22<$ https://www.ditchthelabel.org/wp-content/uploads/2016/04/Annual-Bullying-Survey-2016-Digital.pdf $>$ accessed 3 May 2018.
} 
and being embarrassed about revealing the act of cyberbullying against him/her and the like ${ }^{23}$.

\section{b. Power Imbalance}

Both technological knowledge and anonymity create and contribute to the power imbalance between victims and perpetrators. Although it is a common characteristic of both traditional bullying and cyberbullying, the definition of power imbalance has a new dimension when it comes to cyberbullying. In traditional bullying, for instance, the power imbalance will be between peers, the bully and the victim. The bully who is the domineering passive peer has the power to control the other child. In traditional bullying, power imbalance refers to physical strength, psychological confidence, numbers, popularity or rejection in a group context $\mathrm{t}^{24}$. In cyberbullying cases power dominance is not determined in terms of physical strength, rank, or age but rather technological knowledge and anonymity ${ }^{25}$. However, regarding the power imbalance, two rather new opportunities - technical ability with ICTs and anonymity - become significant. It is assumed that anonymity can contribute to a power imbalance. In other words, if the perpetrator attacks and the victim is upset and does not know the bully or how to defend themself, it creates the imbalance of power ${ }^{26}$. Thus, it is now not only a problem in adolescents or physically weak people. Teachers, for instance, are increasingly becoming the targets of cyberbullies who might happen to be their students. The most common way to bully teachers is to form a hate group on social networking sites containing defamatory comments and to create fake profiles in their names, potentially using non ethical images. When all these reasons are taken into consideration, power imbalance is a unique defining moment of cyberbullying, since without such an element the act of cyberbullying cannot be defined ${ }^{27}$.

\section{c. The Potentially Public Nature of Cyberbullying and Defencelessness of Victims}

A high level of publicity of cyberbullying and its effects that cause massive distress in its victims are the main distinctive characters of this conduct compared to traditional bullying. The constant availability of the internet is one of the causes of the substantial harm to the victim ${ }^{28}$.

When hurtful remarks or sexually explicit content images are posted on a website,

\footnotetext{
3 <https://www.ditchthelabel.org/wp-content/uploads/2016/04/Annual-Bullying-Survey-2016-Digital.pdf $>$ accessed 3 May 2018.

Smitth, Steffgen and Sittichai (n 16) 26.

Betts (n 8) 41.

26 Menesini, Nocentini, Palladino, Scheithauer, Krumbholz and Frisen 'Definitions of Cyberbullying', in Peter Smith and Georges Steffgen (eds), Cyberbullying Through the New Media (Psychology Press 2013) 49.

27 Menesini, Nocentini, Palladino, Scheithauer, Krumbholz, Frisen, (n 26) 49

28 Patel (n 2) 596.
} 
it becomes available to be seen by all. Hundreds of thousands, even millions of users without the usual boundaries of time and space can be directly online via social media and involved in cyberbullying ${ }^{29}$. Social media networks with growing usage could also become platforms for hate speech, defamation and the like. In a similar fashion, an act of bullying which takes place on the Internet would no longer be seen or heard among the members of a tiny community, but it may, in some instances, be accessed by the entire world. It is noteworthy that one who was humiliated by a traditional act of bullying could leave the community and make a fresh start elsewhere. This would no longer be possible for victims of cyberbullying, for the Internet does not forget.

Moreover, if the perpetrator uses bystanders (who under normal circumstances only watch but do not get involved) in social media or e-mail to send bullying messages, the bystander could become the potential participant in tormenting the victim. Just as the perpetrator, bystanders might feel safe in their anonymity ${ }^{30}$. Also, it can be said that bystanders' positions and roles get even more complicated than the traditional bullying when it comes to cyberbullying. Firstly, when a derogatory, defamatory or offensive content is sent or posted by the perpetrator, bystanders can repeatedly visit the relevant website. Secondly when unwanted internet content is received, bystanders may also become participants in this humiliating act ${ }^{31}$.Victims cannot even feel safe in their own homes or bedrooms because perpetrators and bystanders reach virtually via smartphones or PC's directly into the victims' room and consequently cyberbullying is likely to have a very negative effect on young people's health ${ }^{32}$. In other words, it is a plain fact that the digital world does not have any geographical limits; thus the perpetrator does not need to be together with the victim in the same physical environment.

\section{d. Repetition}

Another negative effect of social media is the repetition of the cyberbullying act. Repetition is one of the much-debated aspects of cyberbullying, especially with respect to determination of its proper scope ${ }^{33}$. Repetition may occur in each new view when it comes to cyberbullying. Due to numerous technologic advantages, one act may easily 'snowball' out of the initial control of the bully ${ }^{34}$, after all cyberbullying acts take place more than once. So, the continuous effect of an incident gives cyberbullying act a multi-episodic character ${ }^{35}$. In other words, even if the message was only posted

\footnotetext{
Kai Cornelius, 'Plaedoyer für einen Cybermobbing-Straftatbestand' (2014) ZRP 165; Betts (n 8) 15.

Patel (n 2) 596.

Quing Li, Peter Smith and Donna Cross, Cyberbullying in the Global Playground, (Wiley-Blackwell 2012) 8.

Pelka (n 10) 10 .

3 Betts (n 8) 38.

34 Smitth, Steffgen and Sittichai (n 16) 26.

35 Philip C. Rodkin and Karla Fischer, 'Cyberbullying from Psychological and Legal Perspectives', (2012) 3(77) Missouri Law Review 619, 625.
} 
once, the potential impact on the victim could be endless. Accordingly, cyberbullying is in a sense endless, since once a post is published online it cannot be deleted. This makes cyberbullying unique. Furthermore, people send posts - which are almost impossible to retrieve or undo - without thinking about the consequences of sharing through the instantaneous capabilities of the internet. Repetition in cyberbullying may take different forms. Repeated acts could be committed against the victim where the bully is the same or a single act could be viewed by many different audiences on a number of occasions. When a single act on YouTube or on other web pages is viewed by multiple audiences/bystanders who intend to mock and deride the victim, this exposes the victim to the risk of repeated humiliation because one single act can lead to an extreme number of reposts, without any further contribution from the initial perpetrator ${ }^{36}$. Although the act is not repeated, the negative experience associated with it repeats itself as long as the material is accessible. What matters here is the impact of the action upon the victim, in other words its gravity. Thus, a single act that could be viewed by a continually growing and unlimited audience may be considered as having a greater impact and more severe than a few repeated acts against the victim.

Some definitions of cyberbullying regard repetition as a constitutive element of cyberbullying. Yet, repetition is not a common element in the definitions of cyberbullying in different jurisdictions ${ }^{37}$. Whereas the U.S. law focuses on repeated harm-repetition, the UK focuses on the element of upsetting someone without any requirement concerning the element of repetition.

\section{Cyberbullying and It's Relation to Similar Acts}

Although some scholars scrutinise cyberbullying as a single construct ${ }^{38}$, several types of aggressive behaviours constitute cyberbullying ${ }^{39}$. Acts of cyberbullying include, among others, teasing, insults, hate speech, social exclusion, pejorative names, extortion or threatening the victim via SMS, emails, chatrooms, social networks, blogs, websites, etc. Dissemination of personal information without consent is also a form of cyberbullying. Flaming, as another form of cyberbullying, involves an intense and aggressive dispute via e mail or instant messages ${ }^{40}$. Flaming generally takes place in online forums and settings, such as chatrooms. Generally rude, vulgar language, insults and threats may be brought into the discussion between two people ${ }^{41}$. Denigration means that the harmful, untrue and cruel comments which

\footnotetext{
36 Menesini, Nocentini, Palladino, Scheithauer, Krumbholz and Frisen (n 26) 49.

37 Betts (n 8) 38.

38 Smitth, Steffgen and Sittichai (n 16) 27.

39 Betts (n 8) 19; N.E. Willard, Cyberbullying and Cyberthreats: Responding to the Challenge of Online Social Aggression, Threats, and Distress, Champaign (IL: Research Press 2017).

40 Macenaite (n 1) 7.

$41 \quad$ Patel (n 2) 601; Pelka (n 10) 5.
} 
are spread by the perpetrator can be posted on websites and social media or can be sent to others via mail or instant messaging. By this form of cyberbullying, the victim is not next to the act but the object of the act ${ }^{42}$. Also recording a physical attack and publishing it or showing intimate or embarrassing photos and video clips of a victim in social networks or video platforms is a means by which the bully reads remarks about the victim is known as happy slapping. The purpose is to send it to audience/ bystanders in the hope that it will frustrate the relationship between the victim and their friends or tarnish the victim's reputation.

One form of cyberbullying is sexting. The distribution of sexual images, creating and sharing embarrassing images or videos, and sending sexually explicit messages via social media constitute sexting. In general, sexually explicit messages or images are sent in the context of romantic relationships. When a couple bring the relationship to an end, or when the sexually explicit messages and images are circulated without the victim's consent, sexts can be a mechanism of cyberbullying ${ }^{43}$.

One form of cyber harassment has been criminalised by the Convention of Council of Europe on the Protection of Children against Sexual Exploitations. Article 23 of the Convention requires that contracting parties 'shall take the necessary legislative or other measures to criminalise the intentional proposal, through information and communication technologies, of an adult to meet a child who has not reached the age set in application of Article 18, paragraph 2(For the purpose of paragraph 1 above, each Party shall decide the age below which it is prohibited to engage in sexual activities with a child.), for the purpose of committing any of the offences established in accordance with Article 18, paragraph 1.a(engaging in sexual activities with a child who, according to the relevant provisions of national law, has not reached the legal age for sexual activities;), or Article 20, paragraph 1.a (Each Party shall take the necessary legislative or other measures to ensure that the following intentional conduct, when committed without right, is criminalised: producing child pornography), against him or her, where this proposal has been followed by material acts leading to such a meeting. ${ }^{44}$ ' By means of the article, communication with a

\footnotetext{
Pelka (n 10) 6.

43 Betts (n 8) 123.

44 In the UK Sexual Offences Act 2003, Section 15 became up to date with changes as follows:

' 15 Meeting a child following sexual grooming'

(1)A person aged 18 or over (A) commits an offence if-

(a)A has met or communicated with another person (B) [on one or more occasions] and subsequently-

(i)A intentionally meets $B$,

(ii)A travels with the intention of meeting $B$ in any part of the world or arranges to meet $B$ in any part of the world, or (iii) $B$ travels with the intention of meeting $A$ in any part of the world,

(b)A intends to do anything to or in respect of $B$, during or after the meeting mentioned in paragraph (a)(i) to (iii) and in any part of the world, which if done will involve the commission by $A$ of a relevant offence,]

(c)B is under 16, and

(d)A does not reasonably believe that $B$ is 16 or over.

(2)In subsection (1) -

(a) the reference to $A$ having met or communicated with $B$ is a reference to $A$ having met $B$ in any part of the world or having communicated with $B$ by any means from, to or in any part of the world;
} 
child to establish mutual trust with the intention of initiating sexual contact offline constitutes a crime.

Some types of conduct listed below are classified as direct or indirect cyberbullying in a broad sense. For instance, pressuring the victim into sending sexual secrets or private image material or engaging in sexual conversations, creating false profiles under the real name of a classmate and in doing so spreading false and unkind things, assuming the victim's identity and using it to send harmful or inappropriate messages to others ${ }^{45}$, also spreading rumours by cell phone, email, chat and taking part in voting on a defamatory polling websites, outing of entrusted information ${ }^{46}$, isolating and excluding a person, sending insulting and threatening or abusive messages, exclusion and ostracism, rejecting friendships on online platforms, uploading or sending embarrassed or intimate photos or videos of classmates or teachers on the internet, adding fake photos of the victim to an existing profile or personal websites with other web content, creating and sharing humiliating images or videos, sending explicit messages, inciting young people to self-harm and other dangerous behaviours, voting for or against someone in an abusive poll and the like. ${ }^{47}$

Moreover, it has been argued that cyberbullying is an emerging international public health problem. Researchers investigating the consequences of cyberbullying have shown that detrimental consequences such as increased anxiety, depression, lower self-respect and psychosomatic symptoms, psychosomatic problems increasing the risk of difficulties at school and behaviour maladjustment and substance abuse are all associated with children who have been bullied ${ }^{48}$. For example, a recent study carried out by The National Institutes of Health analysing the effect of cyberbullying showed that victims suffer higher levels of depression because online attacks are more likely to lead the victim to despair, feeling isolated, or helpless ${ }^{49}$. These heavy consequences

(b) "relevant offence" means-

(i) an offence under this Part,

(ii) .

(iii)anything done outside England and Wales F5. . which is not an offence within sub-paragraph (i) . . but would be an offence within sub-paragraph (i) if done in England and Wales.

(3). .

(4)A person guilty of an offence under this section is liable-

(a)on summary conviction, to imprisonment for a term not exceeding 6 months or a fine not exceeding the statutory maximum or both;

(b)on conviction on indictment, to imprisonment for a term not exceeding 10 years.]

45 As an example to impersonation is the Callum case in which the 17 year old perpetrator who set up a fake Bebo account named Callum and tricked his friend into falling in love with fake personality. When the victim learned the joke, he tried to commit suicide. The court asssesed the acts as cyberbullying and imposed a penalty of 250 Pound. Bebo Cyber-bully Faces Jail After Tricking Friend Into Falling in Love with Fake Profile, Daily Mail, Jan.29 2008. <http://www.dailymail.co.uk/ news/article-5371583/Teen-hung-feared-going-jail-like-dad.html > accessed 6 May 2018. Pelka (n 10) 6.

$46 \quad$ Pelka (n 10) 7.

47 NSPCC website, Bullying and Cyberbullying: what are bullying and cyberbullying?, https://www.nspcc.org.uk> accessed 31 May 2017.

48 Marilyn Campbell and Ales Zavrsnik, 'Should Cyberbullying be criminalized', in Peter Smith and Georges Steffgen (eds) Cyberbullying Through The New Media (Psychology Press 2013), 82.

49 <https://www.nih.gov/news-events/news-releases/depression-high-among-youth-victims-school-cyber-bullying-nihresearchers-report $>$ accessed 31 May 2017. 
of cyberbullying have placed the issue to the forefront of the public's attention ${ }^{50}$. It impairs the health of adolescents, since it causes anxiety, loss or damage to selfrespect, emotional disturbance, substance use and suicidal behaviour ${ }^{51}$.

\section{B. Approaches to Cyberbullying in Comparative Criminal Law}

In response to the demands for the new legislation tackling the negative consequences of cyberbullying, some states have started to criminalize acts constituting cyberbullying ${ }^{52}$. These statutes that criminalize cyberbullying fall into two categories. Some of these laws are aimed at modernizing the existing law by adding the element of 'via telecommunications or by electronic means', specifically to harassment or stalking laws. Others have drafted new crimes concerning cyberbullying.

In Common Law countries, such as the United States of America have taken the lead in legislating cyberbullying. Since 2009 several U.S. states have started adopting legislation in which cyberbullying is classified as a criminal offense. Bullying laws target bullying conducted on the Internet or via mobile phones. In the U.S., 49 states have incorporated electronic harassment into existing bullying laws. For example, North Carolina is one of the first states to impose criminal sanctions to cyberbullies and to students who cyberbully school employees ${ }^{53}$.

Although in the UK cyberbullying is not a specific criminal offense, cyberbullying behaviours are incorporated into other crimes such as harassment or threatening behaviour ${ }^{54}$. In the UK four statutes exist that can be applied in cases of cyberbullying. Perpetrators of cyberbullying have been brought before the courts under existing laws such as the Protection from Harassment Act 1997, the Communications Act 2003, the Malicious Communication Act 1988, the Offences Against the Person Act 1861, the Communications Act 2003 or the Criminal Justice and the Public Order Act 1994. For example, in order to protect the victim, the Protection from Harassment Act 1997 is used to prosecute. The Act refers to a 'course of conduct' which is essential to bring a claim before the court ${ }^{55}$. Although harassment is not defined by the Act itself,

s0 In 2006, Megan Meier, 13, hanged herself after being cyber-bullied on MySpace. In 2008, a Brighton schoolboy attempted suicide after persecution on Bebo, another social networking site. In 2009, 15-year-old Cheshire schoolgirl Megan Gillan killed herself, also after being tormented on this site. <https://www.reuters.com/article/us-myspace-suicide/womanindicted-in-myspace-hoax-suicide- accessed 24 June 2019>

51 C.L. Nixon, 'Current perspectives: The Impact of Cyberbullying on Adolescent Health' (2014) (5) Adolescent Health, Medicine and Therapeutics 143, 154.

52 Campbell and Zavrsnik (n 48) 83.

53 § 14-458.2. Cyber-bullying of school employee by student General Assembly Of North Carolina Session 2011 Session Law 2012-149 Senate Bill 707.

54 According to Daily Mail (15 November 2017), the number of cyberbullying incidents jumped by 37 per cent in 12 months, four of ten teacher have had to deal with online bullying in their classroom and online safety experts urge that the problem was getting worse. $<$ http://www.dailymail.co.uk/sciencetech/article-5085475/Cyber-bullying-rocketing-UK-schools.html> accessed 14 June 2017.

55 An example of harassment at the forefront of a cyberbullying incident is the case of Keeley Houghton. In the landmark ruling the 18 year old teenager Keeley became the first to be jailed for bullying on the internet in the UK. After posting humiliating and threatening posts to Emily's facebook profile who is 14 years old, she went to trial and the court gave a 
the Act defers the issue of definition to the courts which will make a case-by-case determination. The Protection from Harassment Act 1997 is considered sufficient to prosecute bullying conducted using social media. Likewise, according to section 1 of the Malicious Communications Act 1988 sending a communication which is grossly offensive with the purpose of causing distress or anxiety shall constitute an offence. These laws can be useful tools in order to provide effective protection of the victim's rights but nevertheless they may be ineffective and outdated struggling against modern cyber problems such as cyberbullying and therefore are unsuitable ${ }^{56}$. The Crown Prosecution Service in the UK released a set of interim guidelines called 'Guidelines on prosecuting cases involving communications sent via social media' which was published in order to set out the approach outlining regulations for communications sent via social media.

According to the OECD Report on the Protection of Children Online 2012, Austria (which has the highest cyberbullying rate in the EU), is a unique example when it comes to the regulation of cyberbullying. Indeed, Austria, unlike other European jurisdictions, cyberbullying has been a criminal offense since 1 January 2016. With a new Article 107c titled 'Continued Harassment Disturbance via Telecommunication or a Computer system', Austria has introduced an offense to its criminal code, thereby being the first European country explicitly penalizing cyberbullying. The legislator chose the term 'harassment' instead of cyberbullying. It is only punishable under Section 107c if it might have an effect of unreasonably impairing the lifestyle of the victim. An actual impairment is not necessary. If the cyberbullying leads to a suicide or suicide attempt, the offender shall be punished with aggravated imprisonment. The crime is primarily concerned with the protection of the freedom of determining one's own life. The section penalizes serious attacks against people and interferences with their personal sphere on the Internet because it is hardly controllable with actions usually having a widespread reach and thereby seriously destroying their personality. The legally protected good of Article 107c/1 is the victim's honour. Violation of honour within the ambit of the Article does not mean the "subjective sense" of honour of the victim, but rather honour in the objective meaning ${ }^{57}$. Distribution of naked pictures of the victim could be an example. The notion of "sense of honour" applies to sexual life, family life, disease, disabilities or religious views ${ }^{58}$. If, for example, the perpetrator spreads awareness of the victim's HIV-disease, this will be regarded as a violation of sense of honour pursuant to the meaning of the offense. Facts distributed by the perpetrator could be true or false. Pictures encompass both photos and videos.

ruling on the act which constituted cyberbullying. This verdict is the first in England to impose a criminal penalty on a perpetrator of cyberbullying. Patel (n 2) 601.

56 Jennifer Agate and Jocelyn Ledward, 'Social Media: How The Net is Closing in on Cyberbullies' (24) 8 (2013) Ent. L.R. $263,268$.

57 Schwaighofer, in Höpfel and Ratz (eds) Wiener Kommentar StGB, (2th, Manz Verlag Wien) para.7.

58 Schweighofer (n 57) para 11. 
The main case in this regard is the distribution of naked pictures. Whether half-naked pictures could be subsumed under this offense depends on the circumstances of the particular case $\mathrm{e}^{59}$. The Article also contains a condition that the violation of honour be perceivable by a large number of people. A large number of people according to the prevailing view in the literature should include at least ten persons. Thus, a private defamatory Facebook message or remark on WhatsApp against a particular person would not suffice. The facts or pictures should be accessible by others. Sending the material to a large number of people or to place it on the Internet or sharing the password of the relevant website would suffice ${ }^{60}$. The action must be continued. Hence repeated action is necessary in the sense of several separate individual actions.

On 17 May 2017, Italy adopted a new law to combat cyber harassment, which makes it illegal to post insults or defamatory messages against minors online, to blackmail them on the Internet or steal their identities. This development is a significant step towards addressing this phenomenon and fill the gap in the legislation that is still present in many other EU countries. The law is dedicated to the first victim of cyberbullying in Italy, Carolina Picchio, who killed herself by jumping from her window after being cyberbullied with a video of her apparently drunk at a party, which was subsequently posted on Facebook, sparking a barrage of abuse online from an ex-boyfriend and his peers. It is for the first time that the legislation provides a specific legal definition of cyberbullying in Italy. The law makes cyberbullying acts illegal 'by using the internet to offend, slander, threaten or steal the identity of a minor, and allows the victim or their parents to demand from the website hosting abusive content to remove it within 48 hours ${ }^{6}{ }^{61}$. Cyberbullying is defined as; (i) any repeated aggression / harassment; (ii) aimed at causing anxiety/fear; (iii) through, inter alia, psychic violence/pressure, the threat of personal injury, etc.; (iv) by means of any telematics platform including telephone, the internet, social network, instant messaging.

Spain is also one of the few EU countries to have a specific provision for acts constituting cyberbullying in their legislation. According to article 173 and 169 of the Spanish Criminal Code, 'a fine or imprisonment can be imposed on whoever harasses a person insistently and repeatedly through a range of behaviours seriously altering the daily life of the victim, such as contacting the victim through media'. The Article determines aggravating circumstances with regard to cyberbullying. For example, if the victim is vulnerable because of his/her age, and if the perpetrator has an emotional connection with or is related to the victim ${ }^{62}$.

\footnotetext{
59 Schweighofer (n 57) para 12.

60 Schweighofer (n 57) para 13.

$61<$ https://www.lastampa.it/2017/05/19/esteri/italy-passes-first-law-to-fight-online-bullying > accessed 16 June 2018.

62 Prevent and combat cyberbullying: is the current regulatory framework sufficient?, <http://www.jei.it/infogiuridica-jei/ item/487-prevent-and-combat-cyberbullying-is-the-current-regulatory-framework-sufficient> accessed 17 June 2018;
} 
In Ireland the Harmful Communications and Digital Safety Bill came into force in 2017 to tackle online abuse. Article 5 of the Harmful Communications and Digital Safety Bill creates new criminal offences to deal with posting intimate images online without consent. Even though using the term cyberbullying or bullying is avoided in the Bill because of the lack of the agreed definition of it, it is accepted in the most serious form of harmful communications. Harmful communications covers cyberbullying with a broad sense and the Bill describes harmful communications such as the intentional victim-shaming of individuals, intimidating and threating messages, non-consensual taking and communication of intimate images, harassment ${ }^{63}$. With the Bill, the offences when committed by means of communications become part of the criminal law system. The offence of sending threatening or indecent messages is extended to apply to online communications. According to Part 2 of the Bill, in accordance with article 4: 'Distributing intimate images without consent, or threatening to do so, with intent to cause harm' with article 5: 'taking or distributing intimate images without consent taking or distributing intimate images without consent' and with article 6 'distributing threatening or false messages' are now criminal offences.

In Germany, cyberbullying has become a fast-growing problem. Although in Germany cyberbullying is not a specific criminal offense, conduct that constitutes cyberbullying can be regarded as an offence that falls within the scope of other crimes such as that of insult (as defined in German Criminal Code 'dStGB' art.185); stalking (as defined in art. 237); or violation of intimate privacy by taking photographs (art.201a); dissemination of depictions of violence (as defined in art.131); defamation (as defined in art.186); threat (as defined in art. 240). A study in Germany has shown that one in every three children aged between 10-18 are the victim of cyberbullying ${ }^{64}$. Therefore, at the yearly conference, organized by the ministers of justice, it was announced that Germany should fight against cyberbullying. Justice ministers were not only concerned about the growing number of insults and defamation on the internet but also emphasised that although insults and defamation are crimes according to the Criminal Code, cyberbullying has a different quality of injustice because of the huge numbers of internet users who can perceive the unhindered comments of unpleasant situations ${ }^{65}$. For this reason, cyberbullying acts may not be covered by the applicable criminal law and it is needed to have the necessary measurements ${ }^{66}$. The German Lawyer Association (DAV) announced that the articles of the German Criminal Code listed above are enough to tackle the problem of cyberbullying. The

\footnotetext{
$<$ https://www.euractiv.com/section/social-europe-jobs/news/cyberbullying-a-creeping-phenomenon-only-punished-bylaw-in-spain/> accessed 17 June 2018.

63 Law Reform Commission, The Report of Harmful Communication and Digital Safety Bill, (2016) 42.

64 Cornelius, (n 29) 164.

65 https://www.lto.de/recht/nachrichten/n/justizministerkonferenz-2014-mein-kampf-cybermobbing-korruption/ accessed 13 September 2018.

${ }_{66}<$ https://www.udldigital.de/justizministerkonferenz-neue-beschluesse-zu-cybermobbing-und-justiz-it/>14 September 2018.
} 
DAV also emphasised the importance of the adoption of preventive measures outside the realm of criminal law ${ }^{67}$. Contrary to the DAV, the former North Rhine-Westfalia Minister of Justice Thomas Kutschaty was of the view that defining a new type of crime regarding cyberbullying is necessary and he claimed that if such a definition were adopted, the victim could report the crime more easily and quickly ${ }^{68}$.

\section{Legal Challenges in Drafting the Legislation for Cyberbullying: Criminalisation and Evidence Issues}

\section{A. General Remarks}

A landmark decision, U.S. v. Lori Drew in 2009, the so-called Magen Meier case, showed how a lack of a definition of cyberbullying could lead to gaps in the coverage of such behaviour under existing laws. Mr. Drew was only convicted of violating MySpace's terms of service, which, in turn, caused demands for enacting specific laws to tackle cyberbullying in order for cyberbullies to be held responsible for their actions. Lori Drew was accused of 'accessing a computer without proper authorization in violation of the federal Computer Fraud and Abuse Act' and in said case it was an infringement of the rules on MySpace's terms of service. On appeal, the federal court quashed the decision of Drew given at first instance, sentencing that a federal law that 'makes violating a website's terms of service a crime is unconstitutionally vague'. The terms of service of MySpace fell short of the standard set by the Supreme Court which requires laws to have relatively clear guidelines as to prohibited conduct. For example, Internet service providers are completely immune from tort actions for allowing third parties posting that which is known to be of harassing nature and not taking any action against it.

In this regard, Liskula Cohen brought a lawsuit against Google in the U.S. to find a cyberbully who had tagged her as 'a skank and a ho' on a blog website ${ }^{69}$. The aim with regard to the case was to force Google to reveal the identity of the blogger so that she could open a case of defamation ${ }^{70}$.

Another case called 'Clementi' brought the substantive criminal law matter to the attention of the public, which showed how cyberbullying can devastate a victim's life leading to suicide ${ }^{71}$. In the literature, it is argued that the current criminal law does

\footnotetext{
67 Press release of DAV < https://anwaltverein.de/de/newsroom/pm-19-14?page_n27=143 > 4 October 2018.

$68<$ https://www.heise.de/newsticker/meldung/NRW-Justizminister-fordert-Paragraf-gegen-Cybermobbing-2072> accessed 3 May 2018.

69 Cohen v. Google Inc. (2009) 887 NYS. $424 \mathrm{ff}$.

70 Details of the case shall be discussed under III.I.c of the study.

71 Tyler Clementi, who was 20 years old student, committed suicide after being spied on by his roommate Ravi. Ravi installed a webcam in his room in order to watched Clementi's intimate moments with his gay friend and tweeted with the comments by inviting the other students to the Show. <https:/www.nytimes.com/2016/09/10/nyregion/conviction-thrown-out-forrutgers-student-in-tyler-clementi-case.html $>$ accessed 9 September 2018.
} 
not provide sufficient protection of an individual's privacy rights in a digital context. Thus, using civil and tort law might be a solution to seek justice ${ }^{72}$. Prosecutions against cyberbullies could be brought under the law associated with assault, threat, sexual offences, stalking, harassment, and torture. However, present crimes remain incapable of punishing each cyberbullying act and perpetrators cannot be held responsible for their actions. For this reason, the approaches of national legislation are often show reluctance to react against cyberbullying. Despite the debates and lack of clarity surrounding the legal aspects of cyberbullying, there have been calls for specific criminal laws to tackle cyberbullying.

\section{B. Legal Challenges in Drafting the Legislations}

\section{Should Cyberbullying be an independent criminal act?}

Regarding the legal measures to be taken in the field of criminal law, law makers may face new challenges. The challenges in drafting legislation is a very controversial subject and has faced criticism. First of all, it has been debated by the scholars whether cyberbullying should be an independent criminal act. Indeed, the current legal regimes regard the phenomenon of cyberbullying as an act of tort rather than a criminal act, which has been criticized in the literature due to the fact that the law as it now stands does not satisfy the needs of victims. On the contrary, it is disputable whether cyberbullying can be analysed as a criminal act and could be regulated by laws related to assault, threats, extortion, stalking, harassment, indecent conduct, torture, cyberstalking and telecommunication offences ${ }^{73}$. It is claimed that the new intended cyberbullying laws targeting cyberbullying acts risk over-criminalizing by creating new crimes that overlap with existing ones ${ }^{74}$. Undoubtedly acts that constitute cyberbullying may also satisfy the definitional elements of other types of offences under domestic laws. Nonetheless, the main problem is whether cyberbullying should be a crime per se or should it be treated as harassment, for instance.

First of all, it should be scrutinized with regard to the purposes of criminal law and reasons why a certain act should become a crime. In the broadest sense, both civil and criminal codes intend to create and maintain the good of society by way of prohibition and requirement of special conduct. However, in the preservation of social order, the criminal law plays a unique role. One of the key roles is to prohibit people from doing acts which have harmful effect on others or society. The purpose of the criminal law is to protect social order.

\footnotetext{
M. Schultz, 'The Responsible Web: How Tort Law Can Save the Internet' 5(2) (2014) Journal of European Tort Law 182, 204.

73 Betts (n 8) 129.

74 Lyrissa Lidsky and Andrea Pinzon Garcia, 'How Not to Criminalize Cyberbullying' (2012) 77 Missouri Law Review 693, 697.
} 
In order to criminalize behaviours, two leading principles govern the criminalising process. One of them is the harm principle generally used in Anglo-American Law and the other is the legally protected right principle particularly used in continental law. According to the harm principle a behaviour should not be criminal unless the behaviour causes harm to others. The principle was initially designed to hinder the criminalization of conduct that has their origins in moral or paternalistic grounds. Despite the fact that the principle has been widely accepted, there has been debates over the term of harm because criminal law is not only brought to bear in taking action against the perpetrators who cause of direct harm to other people but also causes harm to the state, public morals and the environment. In addition to this, criminal law goes far beyond the direct harm and punishes conduct which may not cause harm but put others or perpetrator himself at risk ${ }^{75}$.

As another principle, legal good, which finds its origin in the idea that all offenses are there to defend specific legally protected interests, has an important role in criminalization theories ${ }^{76}$. The common definition of 'legal goods' is based on the goods or values of a particular society that may be mirrored in and protected by the $\operatorname{law}^{77}$. According to the principle, in order to decide whether a legal good is worthy of protection by the criminal law, two main requirements must be examined. The first requirement is that the entire good must be of essential social importance and the second requirement is that the good requires an essential interference of the criminal law. The purpose of the legal goods concept is to limit the intervention of criminal law properly ${ }^{78}$. Continental legal thought when dealing with the interpretation of the Criminal code's provisions, defining their objects and interrelation with other norms, in their majority, subscribe to the so-called doctrine of protected legal interests and the concept of the specific protective purpose of a $\operatorname{law}^{79}$. The essential difference between cyberbullying and other crimes arises out of the legally protected right. Repeated attacks over a certain period of time that generate a special mental strain, demoralise the victim and can lead to behavioral changes leaning towards self-injury or even suicide. It is acceptable to say that although some results of cyberbullying are similar to stalking or other crimes, cyberbullying is not based on the persistent action of only one offender ${ }^{80}$.

\footnotetext{
Jonathan Herring, Criminal Law, (8th Palgrave Macmillan Law Masters) 4.

76 Kimmo Nuotio, Theories of criminalization and the limits of criminal law: A legal Cultural Approach, in R.A. Duff, Lindsay Farmer, S.E. Marshall, Massimo Renzo, and Victor Tadros (eds) The boundaries of the criminal law, (Oxford Scholarship 2011) 372 .

77 Nina Persak, Criminalising Harmful Conduct (Springer 2006) 104.

78 Kai Ambos, 'The Overall Function of International Criminal Law: Striking the Right Balance Between the Rechtsgut and the Harm Principles', (2015) 9(2) Criminal Law and Philosophy 301, 305.

79 Gülşah Bostancı Bozbayındır, Criminal Law, in Gökhan Güneysu (ed), Introduction to Law (Anadolu University 2017) 115.

${ }^{80}$ Cornelius (n 29) 167.
} 


\section{Definitional Challenges}

The other main problem in drafting criminal legislation on cyberbullying crime is the requirement of observing the principle of lex certa (certainty principle). The principle requires that crimes should be expressed in a clear and precise language ${ }^{81}$. Anti-cyberbullying legislations should not limit fundamental rights with a view to protecting individuals from physical and psychological harm. Possible legal definitions of cyberbullying are thus of importance in setting clear boundaries between what is legal and illegal ${ }^{82}$. The definition of the norm should not be too detailed or too broad, since it would very likely render the legislation ineffective.

Cyberbullying could also be used as a basis in defining cyberstalking, grooming, sexting or cyber harassment and this definition would lead to incomprehensibility. The main reason for the confusion with the definition of cyberbullying is the linguistic difficulties. Legal discussions and arrangements predominantly take place in the English-speaking world. For instance, grooming and sexting are both special forms of the cyberbullying and constitute crimes. In the same vein, cyberstalking or cyber harassments international comparisons in the majority of non-English speaking World, that is Continental Europe, are more confusing and do not incriminate either stalking or cyberstalking. Eventually, discrepancies in defining cyberbullying or the complete lack of definitions often leave the national laws not to focus on those cyberbullying cases which would deserve regulations up to the level of crime ${ }^{83}$.

\section{Anonymity}

Also, anonymity remains the biggest hurdle in identifying and bringing perpetrators to justice. Potential legislation or articles in penal codes require the cooperation of law enforcement with the telecommunications sector or service providers in order to uncover the identity of perpetrators hiding behind the veil of anonymity. Perpetrators can disguise themselves easily with pseudonyms and IP addresses could be disguised too $^{84}$. The Liskula Cohen case serves here as an example in which the court forced Google to reveal the identity of a blogger who insulted Cohen. The objective of the case was to compel Google to unveil the identity of the perpetrator so that she could bring an action against the blogger for defamation. The court accepted Cohen's request to unveil the blogger's identity as she established that a 'defamation cause of action had merit and the blogger's identity was material and necessary for the action $^{185}$.

\footnotetext{
Smitth, Steffgen and Sittichai (n 16) 89.

ibid 89.

3 ibid 90 .

84 ibid 93.

85 Cohen v. Google Inc. (2009) 887 NYS. 424 ff.
} 


\section{Collecting Transnational Evidence}

The other problem concerning the drafting of criminal legislation is how to obtain legal evidence across national borders. Due to the rapid development of ICT (information and communication technologies) and their complicated structures, it may be a challenge for national authorities to execute the drafting process for cyberbullying and other cybercrimes without international cooperation ${ }^{86}$. In the face of lack of adequate instruments to investigate potential cyberbullying acts, it may be easy for offenders to use ICT's in various ways in the preparation and execution of their computer related offences such as cybercrimes, and cybercrime investigations at the national level can face a risk of failure by reason of the long procedure of investigations and therefore important data is deleted before procedural measures can be exacted. For this reason, digital evidence is a new source of evidence. The main source of evidence for the cybercrimes and specially cyberbullying is digital evidence. Cyberbullies leave digital traces. The evidence for cyberbullying can be gathered merely via ICT technologies and computer forensics ${ }^{87}$. Although the European Convention on Cybercrime - known as the 'Budapest Convention' - does not define nor contain an offence definition concerning all the conducts related to cybercrimes, it is the first international treaty seeking to address computer crime - especially sexual exploitation of children online. The Convention placed the signatory states under obligation to adopt and harmonize domestic criminal and procedural law as well as foster international cooperation. The third part of the Convention defines three general principles with regard to the international cooperation in cybercrime investigations among member states. Article 23 of the Convention requires not only cooperation in international investigations to the widest extent possible but also this general principle should be applied not only to the extent of the convention but also in any investigation where evidence in electronic form needs to be collected ${ }^{88}$. According to articles 23 and 25, the Parties shall co-operate with each other to the widest extent possible for the purposes of investigations or for the collection of evidence in electronic form of a criminal offence. In the European Union (EU), the European arrest warrant is a useful tool to facilitate prosecutions of cross-border crimes, but at international level only mutual cooperation regulated by international organizations are being taken into consideration. In the EU, three different mainstream models currently exist. These are the request model, the mutual recognition model and the availability model. The use of models depends on the material act that is needed ${ }^{89}$. All conventions of the Council of Europe, as well as of the Conventions of the European Union follow the request model. The last Convention of the EU in criminal matters is the EU Mutual Assistance Convention.

\footnotetext{
${ }^{86}$ ITU Report on Understanding cybercrime, Phenomena, Challenges and Legal Response, (ITU 2012) 83. <https://www.itu. int/ITU-D/cyb/cybersecurity/legislation.html> accessed 24 June 2019.

87 See for the detailed information: ibid $240 \mathrm{ff}$.

88 ibid 273.

89 See for the detailed information of the models: Andre Klip, European Criminal Law, (3th Intersentia) 380.
} 


\section{Cyberbullying and European Convention of Human Rights}

Balancing cyberbullying and the freedom of expression is a crucial issue in order to strike a fair balance between freedom of expression and security of the person from each kind of harm. Legislation against cyberbullying should be enacted in balancing acts which would take into consideration the obligation of states to ensure the security of the person's psychological and physical integrity and the freedom of expression. It is noteworthy that the scope of freedom of expression is generally different in common law and continental Europe. While the ECHR pays attention to national constitutional practices, the USA adopts a broader margin of protection to the freedom of expression. Also, in some cases it is obvious that the ECHR has referred to the international Conventions on civil and political rights or other international documents protecting freedom of expression ${ }^{90}$. While the common law has chartered a territory of free expressions very broadly, the ECHR has allowed much broader limitations for freedom of expression.

Article 10 of the ECHR is structured in two paragraphs; 10/1 defines the freedoms protected by the article and 10/2 stipulates the limitations on the freedom of expression. As freedom of expression is not an unlimited right, limitations of free speech are either allowed by the international human rights law or by case law of the $\mathrm{ECHR}^{91}$. In essence, Article 10 is not a shelter for the incitement of violence, hate speech or racism. In addition to this, it can be said that the freedom of expression shall be limited in line with Article 10/2 of the ECHR in order to protect "public safety, prevention of disorder or crime, public order and public morals.' Incitement to violence and hate speech fall outside the protection conferred by Article 10. One of the restrictions of Article 10/1 is in the matter of hate speech. Although there is not a universally accepted definition of hate speech in international human rights law, it is considered a hate speech if such a speech attacks against someone personally based on their race, religion or sexual identity. Hate speech can also be defined as speech which is directed against someone from hated groups on the Internet with the intention of bias or prejudice against him/her.

From a different perspective, cyberbullying is also contrary to the absolute freedom from torture contained in Article 3 of the ECHR. Article 3 of the ECHR protects and guarantees a fundamental right. Article 3 is violated by either inhuman or degrading treatment or punishment or severe violation by torture ${ }^{92}$. Torture is considered by the ECtHR as committed by either through bodily injury or intense physical and mental suffering ${ }^{93}$. Treatment can be regarded as being degrading 'if it was such as to

\footnotetext{
90 Dominika Bychawska-Siniarska, Protecting The Right To Freedom Of Expression Under The European Convention On Human Rights, (2017 Council of Europe) 12.

91 Smitth, Steffgen and Sittichai (n 16) 91.

92 Helmut Satzger, International and European Criminal Law (2th, Beck/Hart/Nomos 2018) para 9.

93 Kalashnikov v. Russia, App no 47095/99 (ECHR, 15 July 2002) para 95.
} 
arouse in the victim's feelings of fear, anguish and inferiority capable of humiliating and debasing them' and attains a certain level of severity.' Generally, the offender in torture cases acts in order to humiliate his/her victim, but also without such an intention a treatment could be considered as degrading treatment ${ }^{94}$. According to Article 3 of the Convention it should generally be applied to state citizen relationships. However, the ECHR has extended the scope of the protection to the citizen-citizen relationship, that is, article 3 prohibition has a horizontal effect (drittwirkung) $)^{95}$. Thus, if the bully's behaviours exceed the threshold of the gravity accepted by the ECHR, it may constitute a violation of article 3 of the ECHR. In some instances, an action of national authorities may lead to a violation of article 3 of the ECHR. Article 3 of the ECHR can be enforceable in cyberbullying acts where a person has committed suicide and one of the causes of the victim's actions is cyberbullying or other negative experiences such as harassment, threats, grooming, in the digital World ${ }^{96}$.

Article 8 of the ECHR protects persons against violations of their privacy and family life. In this regard the Court puts the Contracting States under an obligation to protect victims in a wide range of cases. In such cases, the State is not the primary violator of the rights protected by the Convention but rather the State has insufficient means and structures in order to prevent violations of the protected rights. The following example from the ECHR jurisdiction illustrates how the horizontal effect of article 8 of the Conventions is employed by the Court. Although the case is not itself an example of cyberbullying it shows that private individuals may also violate article 8 of the Convention. The Grand Chamber of the European Court of Human Rights in the case of Sweden v. Söderman ${ }^{97}$ found that Sweden had violated Article 8 of the European Convention on Human Rights because Sweden failed to have in place laws protecting the applicant from being filmed without consent. In brief, according to the Court's decision, Ms. Söderman who was at the age of 14 discovered that her stepfather had a hidden recording camera in the bathroom in an attempt to film her naked while she was having a bath. Upon her complaint, her stepfather was prosecuted for sexual harassment of children and convicted by the court in the first instance. But, the Swedish Court of Appeal acquitted the accused on the grounds of the lack of the intention element of recording Ms. Söderman. The Court of Appeals noted that Swedish law had no general prohibition against the filming of individuals without their consent and furthermore, his conduct may have constituted attempted child pornography but he could not be held criminally responsible for sexual harassment of children. Ms. Söderman brought a case against the Swedish Government under Article 8 of the ECHR with the claim that the Government had failed to provide necessary

\footnotetext{
94 Kudla v. Poland App no. 30210/96 (ECHR 26 October 2000) para 92; Yankov v. Bulgaria App no.1509/05 (ECHR 22 April 2010) para 106. Satzger (n 92) para 35.

95 Satzger (n 92) para 38.

96 Betts ( n 8) 3.

97 Söderman $v$ Sweden, App no. 5786/08 (ECHR 12 November 2013) para $78 \mathrm{ff}$.
} 
civil or criminal remedies against her stepfather's shooting with a hidden camera, thereby violating her personal integrity. At the time of committing the act of filming of Ms. Söderman, the damages due to the lack of protection of her rights under Article 8 of the ECHR had not been remedied by any other provision of criminal law. In Sweden a new legislation was adopted and came into force in July 2013 which was designed to cover such acts as in Ms. Söderman's case. The Grand Chamber was not satisfied that the relevant Swedish legislation at that time had sufficiently protected Ms. Söderman's right to respect of her private life in such a manner that complied with the state's obligations under Article 8 of the ECHR. As a result of the decision, it should be understood that the act committed against Ms. Söderman violated her integrity and no other provision of Swedish criminal law protected Ms. Söderman against the lack of respect for her private life ${ }^{98}$. What is important for our purposes is that there is a legal gap with regard to protection of citizens against such acts. In this case, the absence of both criminal and civil remedies led the Grand Chamber to conclude that the Swedish legislation in force at the time did not adequately protect the rights of Ms. Söderman under Article 8 of the ECHR. Finally, no other provisions in Swedish criminal law at the time could have protected her rights under Article 8 of the ECHR.

\section{Conclusion}

Generally, in various legal systems, there are many loopholes with regard to cyberbullying and similar phenomena. That said, the creation of a 'cyberbullying offence' in its own right is also not easy. Although there are multiple articles in the criminal codes of the national legal systems governing the conducts which cyberbullying is encompassed, the fast-moving development within advanced technology will continue to bring about new means of regulating such acts, eventually allowing cyberbullying activities to transcend the scope of existing crimes. For example, individual harassment can be punishable as an insult or spreading pornographic content as sexual harassment. But many parts of cyberbullying, which resemble tiny fragments in the whole bullying picture, have no criminal relevance, such as the spreading of embarrassing content, posting false information on social networks or excluding people from Internet groups. Also, particular forms of cyberbullying have more harmful consequences. The law is struggling to catch up with rapid developments in information technology. It can adapt either by applying the existing rules to the social situations arising out of such developments or by creating new rules. Firstly, the legislators should look at possibilities offered by the existing rules and only create new rules if necessary and prevent over-regulation of everyday life. Legal theories offer various interpretation methods such as giving courts authorization to interpret the rules so to extend the meaning of existing rules to new situations. If there is no other way, new rules should be created in line with the

\footnotetext{
Söderman v Sweden, App no. 5786/08 (ECHR 12 November 2013) para 98 ff.
} 
existing legal principles codified in the constitution and international human rights law. The definition of a crime must take into account the existence of and respect for human rights and not merely an expression of arbitrary power.

By criminalization of the acts of cyberbullying, legal systems seek to prevent the likelihood of repetition of such acts in the future by other potential bullies. Indeed, criminal law is very much crafted towards prevention, at least in modern criminal law science. One may argue that punishment of cyberbullies would also serve as retribution. But the prevailing rationale in punishing such acts is either appropriate prevention or general prevention - or both. However, cyberbullying is not an issue which can be solved only by means of criminal law. Additionally, there is a debate as to whether acts which constitute cyberbullying should be criminalized or if cyberbullying should be considered a multidisciplinary matter to be dealt with using non-punitive approaches. It can be said that cyberbullying should be managed in multiple areas at the same time. For example, training courses to teachers in order to give them the opportunities to learn about the area of Internet communication could be considered.

Criminalization per se should not be regarded as a panacea for solving the present problem. Further mechanisms such as support of the social media companies such as Facebook or Twitter or Google are indispensable. A prompt and timely removal of the harmful content would enormously contribute to the objective of preventing cyberbullying. Besides, it would be a more efficient mechanism along with the criminal law.

Grant Support: The author received no financial support for this work. 


\section{References}

Agate J. and Ledward J, 'Social Media: How The Net is Closing in on Cyberbullies' (24) 8 (2013) Ent. L.R. 263-268.

Ambos K, 'The Overall Function of International Criminal Law: Striking the Right Balance Between the Rechtsgut and the Harm Principles', (2015) 9(2) Criminal Law and Philosophy, 301-329.

Betts L R., Cyberbullying, Approaches, Consequences and Interventions (Palgrave 2016)

Bostanc1 Bozbayındır G., Introduction to Law (Anadolu University 2017)

Bychawska-Siniarska D., Protecting The Right To Freedom Of Expression Under The European Convention On Human Rights, (2017 Council of Europe)

Campbell M. and Zavrsnik A, Cyberbullying Through The New Media (Psychology Press 2013)

Connor T. P. and Scott J., Integrating Traditional Bullying and Cyberbullying: Challenges of Definition and Measurement in Adolescents, (27) Education Psychology Review 135-152.

Cornelius K., 'Plaedoyer für einen Cybermobbing-Straftatbestand' (2014) ZRP 164-167.

Hargrave A. M., 'Protecting Children from Harmful Content Report Prepared for the Council of Europe's Group of Specialists on Human Rights in the Information Society’ (Council of Europe 2009)

Herring J., Criminal Law, (8th Palgrave Macmillan Law Masters).

ITU Report on Understanding cybercrime, Phenomena, Challenges and Legal Response, (ITU 2012)

Klip A, European Criminal Law, (3th Intersentia 2018)

Kowalski, Giumatti, Schroder and Lattanner, 'Bullying in the Digital Age: A critical review and meta-analysis of cyberbullying research among youth' (2014) 4 (140) Psychological Bulletin 1073-1137.

Law Reform Commission, The Report of Harmful Communication and Digital Safety Bill, (2016).

Lidsky L. and Garcia A., 'How Not to Criminalize Cyberbullying' (2012) 77 Missouri Law Review 693-726.

Macenaite M, Regulation of Children's Online Privacy (Tilburg University Research Master Paper 2012)

Mason K. L., 'Cyberbullying: A Preliminary Assessment for School Personell, Psychology in the Schools' (2008) 45(4) Psychology in the Schools 323-348.

Menesini, Nocentini, Palladino, Scheithauer, Krumbholz and Frisen, Cyberbullying Through the New Media (Psychology Press 2013).

Nixon, C.L., 'Current perspectives: The Impact of Cyberbullying on Adolescent Health' (2014) (5) Adolescent Health, Medicine and Therapeutics 143-158.

Nuotio K., The boundaries of the criminal law, (Oxford Scholarship 2011).

OECD Report on New Technologies and 21st Century Children: Recent Trends and Outcomes, (OECD Official Document Education Working Paper No. 179)

Olweus D., 'School Bullying: Development and Some Important Challenges', (2013) (9) Annual Review of Clinical Psychology 751-780.

Patel K, 'Cyberbullying: What's the Status in England?' (2011-2012) 13 (2) San Diego International Law Journal 589-622.

Pelka P, Cybermobbing und die Notwendigkeit einer neuen Strafrechtsnorm in Deutschland (Grin Verlag 2015) 
Persak N., Criminalising Harmful Conduct (Springer 2006).

Quing L, Smith P and Cross D, Cyberbullying in the Global Playground, (Wiley-Blackwell 2012.

Rodkin P. and Fischer K., 'Cyberbullying from Psychological and Legal Perspectives', (2012) 3(77) Missouri Law Review 619-640.

Satzger H., International and European Criminal Law (2th, Beck/Hart/Nomos 2018).

Shariff S, Hoff D., 'Cyberbullying: Clarifying Legal Boundaries for School Supervision in Cyberspace', (2007) 1 (1) International Journal of Cyber Criminology, 76-118.

Schultz M., 'The Responsible Web: How Tort Law Can Save the Internet' 5(2) (2014) Journal of European Tort Law 182- 204.

Schwaighofer, Wiener Kommentar StGB, (2th, Manz Verlag Wien)

Smith P., Steffgen G. and Sittichai R., 'The Nature of Cyberbullying and an international Network' Cyberbullying through the new media (Psychology 2013)

Tokunga R.S., 'Following you home from school: A critical review and synthesis of research on cyberbullying victimization' Computers in Human Behaviour 26(3) 277-287.

Wang J., Iannotti R.J. and Luk J.W., 'Patterns of Adolescent Bullying Behaviours: Physical, Verbal, Exclusion, Rumor and Cyber' (2012) 50(4) Journal of School Psychology 521-534.

Weber N and Pelfrey W. V. Jr, Cyberbullying-Consequences, Causes and Coping Strategies (Lfb Scholarly Pub 2014)

Willard N.E, Cyberbullying and Cyberthreats: Responding to the Challenge of Online Social Aggression, Threats, and Distress, Champaign, (IL: Research Press. 2007)

\section{Electronic Resources}

<www.europarl.europa.eu/RegData/etudes/STUD/.../IPOL_STU(2016) >,

$<$ http://netchildrengomobile.eu/ncgm/wp-content/uploads/2014/11/EU-Kids-Online-NetChildren-Go-Mobile-comparative-report.pdf $>$

$<$ https://nobullying.com/cyber-bullying-statistics-2014/>

$<$ https://www.isafe.org/outreach/media/media_cyber_bullying $>$

$<$ https://www.theguardian.com/technology/2017/jun/30/british-teenagers-among-worlds-mostextreme-internet-users-report-says $>$

$<$ http://oecdeducationtoday.blogspot.com.tr/2014/10/combatting-bullying-in-schools.html>;

$<$ https://www.bullying.co.uk/general-advice/what-is-bullying/>

$<$ http://www.cnn.com/2010/LIVING/10/04/youth.cyberbullying.abuse/index.html.http://www.nih. gov/news/health/sep2010/nichd-21.htm.>

$<$ http://www.dailymail.co.uk/news/article-5371583/Teen-hung-feared-going-jail-like-dad.html>

$<$ https://www.nspcc.org.uk>,

$<$ https://www.lastampa.it/2017/05/19/esteri/italy-passes-first-law-to-fight-online-bullying>,

$<\mathrm{http} / / /$ www.jei.it/infogiuridica-jei/item/487-prevent-and-combat-cyberbullying-is-the-currentregulatory-framework-sufficient>

$<$ https://www.euractiv.com/section/social-europe-jobs/news/cyberbullying-a-creepingphenomenon-only-punished-by-law-in-spain/>

https://www.lto.de/recht/nachrichten/n/justizministerkonferenz-2014-mein-kampf-cybermobbingkorruption/ 
$<$ https://www.udldigital.de/justizministerkonferenz-neue-beschluesse-zu-cybermobbing-undjustiz-it/>

$<$ https://anwaltverein.de/de/newsroom/pm-19-14?page_n27=143>

$<$ https://www.heise.de/newsticker/meldung/NRW-Justizminister-fordert-Paragraf-gegenCybermobbing-2072>

$<$ https://www.nytimes.com/2016/09/10/nyregion/conviction-thrown-out-for-rutgers-student-intyler-clementi-case.html>

$<$ www.coe.int/t/dghl/standardsetting/media/Doc/(2009)13_en.pdf,p.8>

$<$ https://www.ditchthelabel.org/wp-content/uploads/2016/04/Annual-Bullying-Survey-2016Digital.pdf $>$

$<$ https://www.nih.gov/news-events/news-releases/depression-high-among-youth-victims-schoolcyber-bullying-nih-researchers-report $>$

https://www.reuters.com/article/us-myspace-suicide/woman-indicted-in-myspace-hoax-suicide-

$<$ http://www.dailymail.co.uk/sciencetech/article-5085475/Cyber-bullying-rocketing-UK-schools. $\mathrm{html}>$

$<$ https://www.itu.int/ITU-D/cyb/cybersecurity/legislation.html $>$ 